\title{
Deconstructing African History from Western Historicism
}

\author{
Isaiah A. Negedu \\ Solomon O. Ojomah
}

\begin{abstract}
If a people were to write their own history to be solely accepted as an ideal, it would not be abnormal for them to do so in their own favour. The history of the African peoples as documented by Western literatures, mostly comprises the exaltation of European culture through various stereotypical labellings of African history and culture.In the same vein, most Africans would be tempted to rewrite African history in favour of the cultures/ traditions of the African people themselves. Western historicism, however, has gradually denied the African an identity, primarily by eulogising its vindictive colonial presence in Africa, with the purpose of creating a cultural superstructure for the West. Through critical analysis and the conversational method, we submit that a balanced reordering of history in a sane manner is quickened when informed African scholars in their various disciplines take up the task of historiography to create their own peculiar narrative that will provide both the scholarly agenda and its related content, to set the African people on a course of wholesome prosperity.
\end{abstract}

Keywords: historicism, white supremacy, history, African history, race

\section{Preliminary Observations}

If we are to define history, we will be faced with numerous definitions, not really because there cannot be a holistic understanding of the concept, but definitions of history abound as there are numerous cultures and races. One of the primary reasons for divergence in the understanding of history is that descriptions/definitions create an ideological superstructure for some cultures and races over others. It is on this note that Wilson (2014) in the first part of 
his book: 'The Falsification of Afrikan Consciousness', exposes a Eurocentric underpinning of history that makes devils out of the black race and angels out of the Caucasian race. Jahn long saw the advent of this ideology when he aptly stated: 'For those who expect to see in their fellow men fools, blockheads or devils, will find evidence to confirm their prejudices' (Jahn 1961:20). As long as a human being has a preconceived notion of the inability of his fellow human to produce good music, all he has to do is to make a hell out of every song that proceeds from his mouth. Our ability to distort the personality of people through various stereotypical images creates idols out of gods and turn mere images into witchcraft. It is on this note that history has been defined for the African as the study of the past and because there is a robust future ahead of everyone, history so defined gradually becomes an inauthentic venture since no one wishes to continue to re-live the past. But European historiography is not just a field of study; it is more of an ideology and in a world with various civilizational tussle, every culture and race strive to outperform others. Our understanding of history must take into cognizance not just the past, but the present and future of the African. History is therefore the past and the future in a mobile present.

\section{Western Historicism}

It was the German Philosopher Karl Wilhelm Friedrich Schlegel who first used the word historicism in describing the type of philosophy that places much emphasis on history (Beiser 2007:175). Certain scholars applied the term to the Italian philosopher Giovanni Battista Vico who held that everything is history; from neo-Kantian German philosophers like Wilhelm Dilthey and Wilhelm Windelband who held that social studies and history are caught up in the presupposition of their time, to various Hegelian and Marxist authors. Often, historicism is linked to the view that what is needed is a historical explication of the items being investigated, be it knowledge, society or human nature (Iannone 2001:245). However it is in the wake of Hegelianism that the term had its popularity. In order to dissect Western historicism, Hegel's view on Africa and Rudyard Kipling's view are necessary as they serve as template of Western historicism. Also, relevant to this is Karl Popper's criticism of Hegel even though there was no reference to Africa in his criticism. Views of these scholars would be used as an impetus to understanding historicism in the context used in this essay. 
Historicism, as used in this essay, can better be understood by taking into account the established pattern of some of the major world achievements in different ramifications erroneously attributed to the Western world as a means of justifying the culture of white supremacy. The relevance of Popper's view is his criticism of historicism based on his definition, where he says of historicism, that it is:

an approach to the social sciences which assumes that historical prediction is their principal aim, and which assumes that this aim is attainable by discovering the 'rhythms' or the 'patterns', the 'laws' or the 'trends' that underlie the evolution of history (Popper 2013:8).

Historicism is therefore aimed at the prediction of future social and political outcomes based on presupposed underlying laws of history. This approach to a large extent lies beneath the unsatisfactory historical accounts given by many western scholars accurately epitomized in Hegel and other scholars whose hidden trend is the culture of white supremacy. Historicism is deep-rooted in our social consciousness. For example, theistic historicism identifies God-willed laws of historical development; naturalistic historicism identifies laws of nature, spiritual historicism clings to laws of spiritual development, economic historicism depends on laws of economic development (Popper 2013:8). Western historicism relied on the trend of the supremacy of the Caucasian race.

There is a relationship between Western historicism and theistic historicism. The example of theistic historicism given by Popper is the doctrine of the chosen people that entails the interpretation of history as the playing out of a script written by God on the basis of the assumption that God has chosen a people to function as the selected instrument of His will, and that this people will inherit the earth (Popper 2013:8). In this type of historicism, the law of development is laid down by the will of God. In western historicism, it is not the will of God, but the will of the western world enshrined in the culture of white supremacy that takes the centre stage.

This Pattern or trend in Hegel's view is embedded in his concept of the absolute spirit which is itself the development of the idea of freedom. It was on the basis of the dialectic evolution of the absolute spirit that he gave his view on African history which is not just a prototype of the many western views of Africa but an embodiment of Western historicism. 


\section{Denigration of African History}

Hegel's philosophy of history remains one of the scholarly works that buttressed the denigration of African history as espoused by many western scholars before him and after him, thus his philosophy of history epitomizes Western historicism. In his view, history involves an ineluctable movement towards the ideal, he therefore described history as the manifestation of what he dubbed the 'universal spirit' whose progress is through the unfolding of 'reason' on earth. This description is based on his aim of elucidating the idea of history as a process whereby the absolute spirit attains consciousness through dialectical process involving thesis, antithesis and synthesis. In essence, history as a rational process is a record of the development of human freedom which entails the development of the absolute spirit or reason. In the Hegelian procedure, history entails the act of the world spirit coming to explicit consciousness of itself. World history for Hegel is a long process by which the spirit develops itself to the attainment of perfect freedom and complete selfrealization via the dialectics.

The above process by Hegel began in the Eastern world; the Chinese civilization where the idea of freedom was limited to the despotic emperor with the right to use his freedom according to his will. Among the Indians, freedom was limited to the caste system, but with the Persians, the dichotomy established between good and evil, light and darkness, further the development of the absolute spirit, but they failed to see the synthesis of these contradictions by identifying the unity of all things. The process of the realization of the absolute spirit moved from the East to the Greeks. Hegel attributed much of the world achievements to the Greeks; he opined that:

Greece presents to us the cheerful aspect of youthful freshness, of Spiritual vitality. It is here first that advancing Spirit makes itself the content of its volition and its knowledge (Hegel 1956:223).

The course of the absolute spirit progressed from the Greeks' perception that was deformed by their institution of slavery and moved towards the Romans, which had institutions of law that established better ideas of freedom. The institution of slavery also marred the progress of the absolute spirit. In all, it was with the Roman Empire that Christianity established the idea of freedom by its spreading to the whole of Europe where the idea of freedom is for all men. However, the most advanced process of world spirit coming to 
consciousness in Hegel's philosophy is with the Germanic civilization. It was based on this idea that Popper attributed the origin of Nazism to Hegel's philosophy.

The above general overview of Hegel's view of history of the world has no place for Africa because he viewed it as a non-historical part of the world that is yet to exhibit any idea of freedom. To this end, it was just a mere piece of land with pathetic beings that fed on roots, herbs and the milk of camels. Summarily put, it was a place of madness and absolute deep sadness of the highest order (Mudimbe 1994:8). In order to give reasons why Africa is a non-historical part of the world, he further makes a distinction of what it means to be Africa proper and what not to be termed Africa proper.

Africa proper ... is the gold-land compressed within itself - the land of childhood, which lies beyond the day of self-conscious history, is enveloped in the dark mantle of night. Its isolated character originates, not merely in its tropical nature, but essentially in its geographical conditions (Hegel 1956:91).

The proper Africa in his view is the territory that lies south of the Sahara, the European Africa lies north of the Sahara and Egypt, a territory connected to Asia (Hegel 1956:92). Negro, which is the black race in Hegel's view, is tantamount to Africa. To this end, he relates his view of history as follows:

In Negro life the characteristic point is that consciousness has not yet attained to the realization of any substantial objective existence - as for example, God, or Law - a in which the interest of man's volition is involved and in which he realizes his own being. This distinction between himself as an individual and the universality of his essential being, the African in the uniform, undeveloped oneness of his existence has not yet attained; so that the knowledge of an absolute Being, an Other and a Higher than his individual self, is entirely wanting. The Negro, as already observed, exhibits the natural man in his completely wild and untamed state (Hegel 1956:93).

Another characteristic attributed to the Negroes by Hegel is slavery:

Among Negroes ... parents sell their children, and conversely children their parents, as either has the opportunity .... The polygamy of the 
Negroes has frequently for its object the having of many children, to be sold, every one of them, into slavery [the king of Dahomey had 3,333 wives], and to conclude, of slavery to have been the occasion of the increase of human feeling among the Negroes (Hegel 1956: 97 98).

In accordance with Hegel's portrayal of Africa, reasons for slavery and colonization are apparent because the ways to ensure that the absolute spirit reaches its consciousness in Africa is by slavery and colonization. With regards to colonization, Rudyard Kipling in his poem 'The White Man's Burden' regarded the colonized as the white man's burden, half-child and half devil. Steinvorth (2009:66) relates Kipling's view to Heidegger's view of the authentic self and concluded that:

the West regarded itself as more authentic, less illusionary, more in contact with Being (whatsoever was meant by that word) than the rest

In order to justify herself as an embodiment of humanity through selfrecognition imbued with authenticity, some western scholars for a very long time have been engaged in denigrating Africa, the cradle of humanity and civilization. Albeit archeological evidence and other historical facts have exposed the hidden agenda inherent in the culture of white supremacy.

\section{Historiography Exposed}

Western historiography on the African race begins with plunder (Williams 1987:37). If a Christian is questioned on the nature of the teaching of the gospel, he is most likely to point to the golden rule love (Jahn 1961:17). But if the same person from probably a cultural background different from the African is asked about the African culture, his first reference will be to the primitive man in the forest. If love is really the golden rule of the Christian religion, why will his first reference be to the negativities of the black man in Africa who is devoid of humanity? The Christian era also had its own challenges in the dark ages characterized by the inquisition and various crusades. Justice demands that if primitivity in the forest is what depicts the African, then the inquisition and not love should characterize the Christian era. 
Many institutions of African studies located in Europe are controlled by western scholars and the persons who certainly determine your ideology will most likely also control your collective destiny. Africans cannot claim to be free agents simply because they have acquired education that liberates them from the shackles of the historicism of the West. And because stereotypes are not always in favour of the victims, Africans as the victims are not going to be measured by the awareness of the informed minority, but by the ignorance of the deformed majority. This same very sectarian idea about the African people made some Western scholars conclude in a rush when they saw the vast uninhabited and uninhabitable stretches of land, that there was an in-built inferiority or in-built failure in the very nature of the African (Williams 1987:45). Yakwazulu-Natali is an example of such a city that falls within this categorization; which is to the effect of the discovery of the Yakwazulu on Natalis (birth of Christ). It is not unlikely for the victims to always look for scapegoats outside their environment. However it should be stated that history also has it that the said victims have also been active participants in the philosophy of plunder. This is coupled with the fact that racial stereotyping at various times was indirectly taught by those who should be the linchpin of the colonized. Thus, it provides justification for them to accept their status but also to impact their fellow Africans and Caucasians.

Many among Africans and Caucasians alike were fed with mythological lies about the African society and the life of a black man in Africa. The land of the blacks, they were taught, is the land of barbarians where people are controlled by instinct and not reason and the consumption of human flesh is most prominent. And because cannibalism was synonymous to the African at home, the zoo was meant to be his homeland. Little wonder, Hitler's Germany bought into this narrative and created a safe haven against this 'alien race' in the zoo. But because many Africans have no sense of the authenticity of history, it is hardly recalled that during the era of dispersal, many Africans wandered aimlessly without settlements. These very groups of Africans were either sentenced to enslavement by the Arabs or death by starvation. Those who could survive resorted to cannibalism. Thus, there was a preparatory ground for the justification of the Eurocentric thesis that Africa was a land of primitivity where human flesh eaters were most prominent. Even in the sanest society, civilized human beings may most likely resort to the devouring of human flesh as the only alternative for survival. This was the very condition Lon Fuller presented in the case of the Speluncean explorers. 


\section{$>$ White Supremacy}

In order to understand the basic idea that propels the denigrating view of Africa, the concept of white supremacy is a vital key.

White supremacy is a historical based, institutionally perpetuated system of exploitation and oppression of continents, nations, people of color by white peoples and nations of the European continent, for the purpose of maintaining and defending a system of wealth, power, and privilege (Martinez 2004:51).

This was however not unconnected with Buffon and Blumenbach's racial determinism of the existence of the 'master race'. With their push for the theory of monogenism emerged the fabrication of 'impure race' which was made flesh in the existence of various classification, with the black race being at the bottom. Important to this definition is the politics of power defined as the ability to define reality and convince a people to apply your definitions to their lives. By doing so, in effect, it creates an imaginary world perceived through the manufactured lens of another (Black 2013:369). The kind of history that many have come to believe and live as reality are products of the politics of power, which in relation to the western world, gives Africa its identity, shapes her attitudes, establishes a standard of judging values and behaviors. Jacobson rightly conceived race as organizer of power. This power can be summed as power to control, power to oppress and disempower (Jacobson 1991:11). The ideological content of this power forms the pattern of education in the world today; a system of education that regards African history as tantamount to bondage; a system of education where past achievements of ancient Africans are attributed to White scholars. Hence, the power politics is enshrined in the miseducation pattern of the schools' curricula with broader notarization beyond the sphere occupied by the colonist.

One's history is paramount to the formation of one's identity. The white supremacy as embedded in the philosophy of Hegel and other western scholars is aimed at depriving Africa some historical achievements. Although empirical evidence has rendered this effort valueless to those who have been able to deconstruct the lens of stereotypes introduced by the politics of power. It is therefore necessary to understand that:

the white race is not a passive demographic act but an invented volun- 
tary social institution whose main utility is oppression. It is one that continues to be collectively reinvented in a vain attempt to resolve the contradiction between white political power and social freedom and the denial of the same to (people of color) ... (Rubio 2001:197).

This denial entails denigration of African history and identity of African people. Important to the perception of white supremacy is the politics of colour which entails outright attribution of negativity to black. Unfortunately, the Christian perspective of colour embraces this brand of white supremacy. As recorded in the Christian Bible and portrayed in many contemporary pictures of God and devil, the devil who was once a white angel suddenly became a black figure after he became the devil. This belief unconsciously or consciously lies behind Kipling's portrayal of the black race as half-devil and halfchild because if the devil is black, people of such colour automatically become 'sub-devil'. Also, the black colour is associated with sin, while the white colour is associated with righteousness. This understanding likely lies beneath shameful part played by some Christian missionary in the slave trade era. If sin ought to be condemned, then the black man who carries the image of sin ought to be condemned in slavery. The realization of the past achievements in African history is neglected based on this conception baptized in a 'pool of white supremacy'. What this does eventually is that it led to a kind of violent tendencies amongst the victims in a bid to affirm their humanity. So historiography moved in the trend of monogenism-negromaniac-negrophobia. In other words, from the arrogance of a group, to violent tendencies amongst some others and then to fear of the African by the very race that created the tension. This in turn has made it possible for some members among the colonist to become fragile to the point that there has been a perceived hyper-reactive tendencies and concentration on the plight of the Africans. This in our view has the capacity to stall any proposed healing process. On this note, the victims must also understand that even among the colonist race, some scholars have made attempt to create objective view of history. On this note, we use the concept 'white' and 'black' under protest since western historicism transcends colour.

\section{$>$ The Relationship between Western Historicism and White Supremacy}

Theistic historicism shows its relationship with white supremacy. Just as theis- 
tic historicism regards God as the author of the script that ought to be played out in accordance with divine will and law by the people chosen by God in the same fabricated script, white supremacy is the physical manifestation of Western historicism. Hence, Western historicism presupposes white supremacy because the idea evolved from the shift in focus from the chosen people to the chosen race, where a people were chosen through a racial contract with divinity while the rest of humanity are subsumed into the 'master race'. Wherever there is historicism of any kind, certain pattern, laws or rhythm are held in high esteem as the source of the evolution of history. This script upon which the historicism is based is often regarded as the gospel truth. The falsification of history as inherent in Hegel's view of African history as one of the sources of western historicism is regarded as the authentic history of Africa by most white supremacist. In the view of Browder:

Throughout the last four and a half centuries, racism and white supremacy have continually threatened the existence of African people before, during, and after enslavement. These threats have forced Africans to modify their beliefs, thoughts, and behavior in order to survive on a planet where they are regarded as 'Third World' people. Those who now claim to be members of 'First World' are actually late comers to the human family (1996:3).

Browder's portrayal of the West as the actual late comer is based on various archeological evidence that bequeath to Africa the status of the cradle of civilization.

The relationship between Western historicism and white supremacy can further be explained by viewing western historicism as the theory while white supremacy is the practice. This view is accurate because the practices of white supremacist are based on the birth of ideologies in historicism. The upholders of Rudyard Kipling and Hegel's ideas of the black race and African continent is symptomatic of ideological imperialism.

In compliance with Hegel's view, some other philosophers and scientific historians of Western origin claimed that Africa has no history simply because so much of its past was not documented. This claim is usually based on narrative supported by the writing of African history by Western historians that do not have much knowledge about the African history. This view is flawed by the following argument by John E. Philips who held that: 
The idea that historians work (or should work) only with written documents has had unfortunate effects on history in general (imagine if detectives were only allowed to introduce written evidence in court!), although the lack of written evidence for much of African history has mitigated those effects on the history of Africa. The idea, borrowed from literary criticism, that nothing exists outside the text, useless for history (2005:39).

Also, since history is first of all conceived as an idea before it is penned down, it may certainly lead to a whole lot of problematic questions, one of which is the possibility of the study of history simply in books. Even so, in the fullness of time, the notion of orality without documentation will have to be debunked through various forms of writings either in forms of drum script, alphabetical script, hieratic, hieroglyphics, nsibidi and some others yet to be discovered. Based on this argument, the problem of African history is not documentation as such but the written script of the Western historicist that is the norm for others to follow. This is the practice of white supremacy that is inextricably interwoven with Western expansionism that culminated in colonialism and slavery.

Since Africans have been bedevilled by Western historicism and its brain child white supremacy, it is therefore necessary for the Africans to become the narrator of their own history not on the ground of sentimental reaction, but on the reality of authenticity, because history from a biased point of view cannot be regarded as history. A white supremacist view of African history is not a history in all its ramifications. It is pertinent to view Africa through the lens of Africans with real knowledge and not through Westerners with biased mind. This calls for Africanization of African history by disregarding the Westernization of African history which is a product of Western historicism. In the words of Brizuela-García:

It was necessary first to rid the writing of African history of the prejudices and limitations imposed by traditional colonial and European history. In this regard the methods, questions, and sources used by historians in the writing of African history needed to be Africanized. Secondly, it was assumed that more of the personnel involved in the writing of African history and the institutions 
supporting this endeavor would be based in Africa, connected to African societies and their everyday problems (2006:87).

This calls for curricula for African schools that are based on Africanized history. In the final analysis, historicism is not all together evil in itself as it has created in the victims the extent of lack of awareness on their part and thus opened the Pandora's Box for discourse that takes into cognizance the inclusivity of the colonized.

To forget the past historical achievements of a whole continent where human beings originate is to forget the origin of humanity with important aspects that can only be traced to the origin. The past ought not to be forgotten as inculcated into our education system by the white supremacist. Even though the heinous effect of white supremacy seems to have become part and parcel of the being of many Africans, it is pertinent to reiterate the words of Malcomson who opined that:

I doubt the past can be apologized for in any case, because it is beyond the reach of forgiveness. The past can only be understood and integrated into the present - its effects on the present recognized and incorporated into a daily practice of repair that cannot have an ending any more than the past has an ending (Malcomson 2001:507).

In order to understand the past, we shall state certain accomplishments in history that have been subjected to the evil of white supremacy. This understanding would help us in placing African and the negro race in their place in past, present and future.

\section{Africa in History}

There is power in definitions and historical explications that make it possible for people to define concepts and convince us that those definitions are ours. By doing so, we come to own definitions that were imposed on our consciousness. It is pertinent to note that there are several imposed ideas in theory and practice that Africans have accepted as part and parcel of the historical truth and included some directly or indirectly, in their educational curriculum. This inclusion in the curriculum forms part of the system of racial power being perpetrated in the guise of history and education guidelines. 
Whenever references are made to past achievements of Africa in history, several scholars including Africans limit progress to Egypt as the only African country whose ancient history is replete with great achievements. Contrary to this belief system established about Africa, Jochannan pointed out that Egypt is one of the last of the ancient culture along the Nile. The importance of Egypt is not premised on the fact that it led any African society in antiquity, but that it is the society where most of the artifacts have remained engrained in stones. He also states that in terms of record on civilization, we can place societies of Africa at the head waters of the Nile; Ethiopia, Uganda, Somalia, Kenya, and Tanzania (Jochannan 2013). He further noted along with Clarke that the early Egyptians in the second and third dynasty '.. came from the beginning of the Nile where God Hapi dwells, at the foothill of the mountains of the moon' (Jochannan \& Clarke 1991: 83-84). Rwenzuri in Uganda and Kilimanjaro between Kenya and Tanzania are both called Mountain of the Moon in their respective countries. The fact that Egyptian civilization was not the first was reemphasized by Rensberger who held that:

Evidence of the oldest recognizable monarchy in human history, preceding the rise of the earliest Egyptian kings by several generations, has been discovered in artifacts from ancient Nubia in Africa .... the various symbols of Nubian royalty that have been found are the same as those associated, in later times, with Egyptian kings (Rensberger 1979:16).

Rensberger also opined that the first king of Ta-Seti (Nubia) may have ruled about 5900 BC. This assertion affirms Jochannan's historical overview that 'Nubia is the mother of Egypt just as Ethiopia is the mother of Nubia and just as Somalia, Kenya, Uganda is the grandmother of Egypt' (Jochannan 2013). Williams devoted an entire chapter with the title: 'Ethiopia's Oldest Daughter: Egypt', where the advent of Ethiopia before Egypt is further explicated. The reason Egypt is regarded as the last of the ancient civilization is that; no society in human history started at the end of the river and walked up against the current of that river, because the means by which men travelled up the river is by locomotion with the log of wood and Egypt is at the lower part of the Nile. Hence the use of log of wood as a means of transportation on water remains an ancient means of humanity's transportation. 


\section{$>$ Miseducation of Africans and the Falsification of History}

No nation can afford to treat with levity the education of its citizens, since the kind of education a people receive either make or unmake them. This is very important because a weak educational system translates into a frail economy in the future. Our economy is largely a reflection of the education bequeathed to us and the quality of our economy cannot be better than the quality of our education.

Fortunately, while the education received in some advanced nations prepares them to meet the demands of each age, that bequeathed to Africans kept them in a static position. Such industrial education that was necessary to meet the challenges of every season that was and is still being received by the blacks, was merely to master skills already relegated in progressive societies (Woodson 2010:15). This was a deliberate attempt to perpetually relinquish the blacks to the Stone Age. Even the study of history has been distorted to remove Africans from the scene of events. European historiography presents the African people as a race that was once upon a time, not a people, but has been grafted into the siblinghood of humanity through Western benevolence. It is partly this distorted knowledge we have about Africa that constantly and consistently depletes our identity. No one expects a master to reproduce his own history, while at the same time exalting a slave. History as long as it is written and taught by the conqueror, will always be written and taught to his advantage. Thus, when we hear names of towns and historical events such as; the University of Djenne (University of Sankhore in Timbuktu), the story of the scramble for Babatus and the ploy of king Necho II, which dates as far back as 600 B.C.E. (Babatus was later renamed Cameroons), Goshen which is the birth place of Moses (which is actually in Egypt), what we simply do is project whiteness into them, without at the same time knowing that the renaming of cities and events in Africa was a preconceived ideology by the colonial masters since it aids in the distortion of African history. We could therefore clearly be reading history about ourselves, attributing greatness to those who accomplished such historical projects, without at the same time knowing that we make reference to our ancestors.

When we go through history and view some alleged treaties that Africans supposedly made with the Europeans, we would also note that there were some forms of historical forgery made at a time when there was no 
English language, yet African leaders made and signed treaties in English (Jochannan \& Clarke 1991:18).

Nobody speaks of the plunder of a virgin land, for humans only struggle for domination in a world where fellow humans live. So when Hegel referred to Africa as a continent that is unhistorical, without movement or development, it is a contradiction of the very scramble for Africa which started as far back as 1675 B.C.E (Jochannan \& Clarke 1991:16) and is still been scrambled in the present era. This same continent without a history is the same continent that transported a life of contemplative devotion into Europe, a people that had a conception of resurrection and immortality long before the Christianization of those ideas in Europe; a continent that pioneered foundational patriotism in an organized form (Diop 1987:19, 32) with an organized political, economic and even educational system Or have we also forgotten that the only authentic form of art in America is jazz and that jazz could not have been feasible without the rhythmic structure of Africa and the drums? (Awoonor 2006:86). Even the tales and folklore of the people of America are not original to them (Du Bois 1994:7).

There is, therefore, a great need for a new historiography of the African race by the African people themselves, not a history that is based on the adventures of Europe but that is premised on the life of the African and the very things that characterized the essence of their being.

\section{$>$ Where are the Women in all of These?}

The special attention given to women is in a bid to make it both more gender balanced and to emphasize that aspect of African history that is always negligent. This is not in any way to pave the way for affirmative action. It is our submission that affirmative action sub-humanizes the women folk since it proceeds from a status of deformity that is in need of empowerment. This is not a product of western historicism as such, more than it is a product of a patriarchal chauvinistic society to always assert male dominance. This is in addition to the fact that the lineage system of the Africans had hitherto been matrilineal, but was changed with Asian invasion. To this end, the influence of women had always been unequal to that of men and in some cultures it happened without animosity from the men folk. In the fullness of time, powerful rulers in history felt the imperial command and vigour of some of these women whose roles to a large extent defined and redefined the African 
continent. One could therefore not have imagined that while Alexander the Great was on a voyage of conquering empires, he would have been too ashamed to stand the humiliation of the command of Queen Candace (Williams 1987:118). This led him to have a retreat with his army from going into Ethiopia. Being the oldest daughter (Egypt) of Ethiopia, it was very likely that had Alexander been able to penetrate Ethiopia, Egypt would have taken to its heels, or rather been too weak to confront the enemy.

Politically, from the pre-colonial period, women overcame difficult challenges in their societies and at the same time advanced the politics of their communities. In that period, they acted as queens, queen mothers, female chiefs, political advisors, law-makers, regents and individual women whose historical status and political responsibilities and contribution equalled that of prominent African men (Ogbomo 2005:355-356).

Their access to political power during this era enabled them to contribute to their various societies. This is however hinged on the fact that African women first gained economic and social status before they obtained political position, making it possible for them to exert influence. They gained influence by means of being wives or through their husbands, heredity, power and position through hard work, diplomacy, strategic warfare that was difficult for virility to attain, strength of character and personalities, the political system, economic structure, ritual prowess, etc.

Under arms, ruling Queens led troops to battle not as ceremonial figureheads but as effective war leaders. They had opportunities open to them. Adjepong gave examples of some of these women; Mamochisane of Zambia (whose father founded the Kolola Kingdom) who controlled one of her father's regiments against the Lozu people of Zambia; Okyenhene Afia Dokuaa of Akyem Abuakwa of Gold Coast (Ghana) who took up arms in defence of the independence and sovereignty of their kingdoms, which is the reason why a horn music is played in her honour at the Kyebi palace (Adjepong 2015:2527). Ibn Batuta gave account of the women of Walata who traced their ancestry to matriarchal affiliation and the women were given more respect than the men (Windsor 2003:91). All these happened without resentment. Other women whose military exploits cannot be ignored are, Queen Nzinga Mbande of Angola of the Ndongo kingdom. She is also described as a great female soldier, diplomat and a heroine of advocacy against the slave trade. She played a major role in the Ndongo's opposition to the Portuguese imperialism in Southern Congo; Moremi of Ife (a warrior queen), Queen Amina of Zaria (a warrior and 
a conqueror) who engaged in years of uniterrupted warfare; Queen Mma Ntatise who ruled as a regent in Kwazulu-Natal (Coquery-Vidrovitch 1994:40). These women sometimes exercised enormous power and authority which aided in the efficient administration of the society.

As political advisors and lawmakers, they contributed to the development of their societies through decision making, good counsel and adjudication. They also served as checks on Kings. Evident among them was the queen mother of Kanem Borno known as Magira, the first wife called Gumsu. They were revered because of the power they possessed. They use their status to dethrone or remove tyrant kings or to prevent the emergence of a tyrant leader. They also mobilised the populace from their lineage and its supporters and allies to bring to the throne the king of their choice. Loyalty is sometimes to these women and not to the kings (Adjepong 2015:28-29). In some cases, these women along with kings occupied topmost political position in the society. They presided over the highest courts, summoned gatherings, allocated lands, disbursed wealth and assisted in the organization of social/ceremonial activities. They advised the king on important matters. They aided in the formulation of laws which allowed for the smooth administration of the society. The collapse or survival of societies depended/ is determined by the bad/good counsel of the queen mothers.

As queens, chiefs and regents, women political engagement is not limited to the military services or to mere advisory bodies to males. The queen mothers assist kings in the efficient administration of societies. In this capacity, women had direct political control and opportunity to exercise their political skill. For instance, the Ogiso (Paramount chief) had 31 females who governed and shaped the politics of pre-dynastic Benin (Ogbomo 357). Agua Brafo ruled Efutu in 1700 for a short period in Gold Coast (Ghana), Tuteba reigned in Agona between 1680 and 1700 . Her reign was characterised by a period of economic prosperity in Agona also in Gold Coast (Ghana) and she determined which European country and merchants carried out trading activities in her territory. It is however pertinent to state that she equally controlled the trade of Agona. Other women of Gold Coast (Ghana) origin include Amaa Serwaa, Afrokoma I and Aku Sapomaa, all of Dwaben in Asante (from 1840 - 1875) in succession. The contribution of queen Amina of Zaria of Northern Nigeria to political development cannot be forgotten hastily. As the queen of Zaria, she played a great role in the rise and fall of Zaria during the 16th century. Her reign is characterised with thirty-four years of uninterrupted warfare. Due to 
Islamic ideology and practice, she is referred to as a mythical figure because sectarian religion did not accord women importance in the society specifically in public affairs. Traditional accounts however make reference to her as a leader who brought great prominence to her area.

Queen Yoko of Sierra Leone grew to the rank of a queen and powerful woman due to her marriage to a warrior called Gbeje. She secured her husband's freedom from the British who arrested him. As a result, he elevated her to the status of the head wife, sent her on diplomatic and political mission in a bid to advance herself as a prominent female political figure. She succeeded her husband as queen. To ensure the growth and survival of the kingdom, she initiated peace treaties with other kingdoms when her kingdom was involved in conflicts with its neighbours in order to prevent war. She refused to consolidate on her husband's policy of expansionism through wars of conquest. Realising the economic, political and social dangers of emigration particularly of its labour force, she avoided policies and programmes which might encourage the emigration of her subjects. Therefore, she devoted her time and effort to the consolidation of Kpa Mende kingdom. As an outstanding, intelligent and great diplomat, she successfully exploited her good relations with the British to achieve her ends.

The Tonga women of Central and Southern Africa had opportunities to occupy higher political offices and therefore contributed to the development of the society though, submissive to their husbands. As female chiefs, they had power over relatively limited units of production. In this regard, many women established their own settlements and governed them. To gain their autonomy, some of them left their husbands and formed their villages which they settled with their relatives. Examples are: Namulizili who divorced her husband to establish her own village with five of her unmarried children, a married daughter and her husband, a sister and her son, another sister and her husband and six other groups. Another woman is Civi who also left her husband and founded a new settlement with her sons, brothers and other male relatives. Also, Matimba established a village with fifteen adults and six children who worked on her fifteen acre farm. Mamochisane of Kolola kingdom of Zambia gained her power through her personality and bravery. She administered the central province of the kingdom. She succeeded her father, but since it is a patrilineal system and to maintain peace and political stability of her kingdom, she reigned as a surrogate for a while and abdicated in favour of her brother (Adjepong 2015:34-35). 
In the 19th century, Queen Mma Ntatise, the first wife of Chief Mokotjo is also a regent of Kwazulu-Natal throne of South Africa. After the demise of her husband, she managed the kingdom on behalf of her young son at the expense of her brother in-law, who by custom should have inherited the throne. As a ruler, she asserted the independence of her people, the Tlokwa, from other Sotho people in South Africa and declared war on Moshweshwe, the Chief and founder of Lesotho. Between 1822 and 1835, Ntatise fought several wars against neighbouring people and won many of them (Adjepong 2015:35-36).

The first Ata of Igala who was a woman reflects the political place of women in the pre-colonial period. She was the first traditional ruler to occupy the throne of the Ata. Ebulejonu was a mystical female warrior who fought her way to Idah along with some followers. This explains why the Ata Igala have their ears pierced like a woman in her memory.

Madam Tinubu, an entrepreneur who traded in articles such as tobacco and salt in Badagry, as well as expanded her business during the European slave trade as a middleperson and became hostess to the exiled king Akintoye of Lagos in 1846. She inaugurated a pro-Akintoye movement in 1846 and dedicated it to the reinstatement of Akintoye as king of Lagos, who eventually regained his throne in 1851. In her desire to extend her business, she included ammunition such as gunpowder and bullets into her business venture. She equally contributed to the successful defence of Egbaland during the Dahomean (Republic of Benin) invasion of 1863 and was awarded with the title Iyalode and also installed the candidate of her choice during the Alake succession crisis of 1877 (Ayobade 2012:231-232).

In pre-colonial, colonial and post-colonial times, African women have not been idle in the developmental process. In as much as men benefited from Western education more than women, the few educated women did not allow the limitation presented to them by institutionalized patriarchal system to hinder them from actively involving themselves in the endeavours that will advance the continent.

\section{$>$ The Quest for a Decolonized Religion}

The whole concept of religion is not a coinage of the supernatural, but a formulation of man to bring the human person closer to the consciousness to the suprasensible. The Christian religion becomes our victim in this research because large parts of Africa were colonized by nations that opined that 
salvation comes only through the Christian route. Thus, one of the criteria for slavery was the fact that a people or a nation was unchristian. Religious tyranny operating under the form of religious authority gave permission to every nation in Europe to reduce every man in Africa to servitude who never accepted the Christian religion. It is an indicator that Africans have been a spiritual people before slavery since one of the primary reasons for Africa's enslavement was that the people were not Christians. Not minding the form of religion being practiced by a people in Africa, its basis of reducing an entire race to the level of animals was the fact that they believed in the Supreme Being in a way that the Europeans didn't believe. The justification of the enslavement of the African people was further given a biblical foundation. Was it therefore not a preconceived coincidence that the bible, which started as a colonial tool, was given to the black man with various verses that endorsed slavery, as a divine order? It would be sheer absurdity and a deliberate denial that has its foundation on irrationality, to conclude that the idea of religion was unknown to the African people before the emergence of the white man. History, however, has revealed that there is virtually nothing that is found in Christianity that is new to the human person, except for the untrained mind. Since the African people vividly had the knowledge of the supersensible before colonialism, there must be reason(s) for the establishment of an organized religion as imported into various colonies.

When we go through the various mythologies surrounding the concept of death and the afterworld of the Bantu people of Africa, the Masarwas, the Ashanti, the Nandi and Wabende peoples of East Africa, etc, we would understand that pre-colonial Africa did not only have organized religions, but also an elated form of spirituality. Thus, when Lightfoot and Ussher announced that the creation of the world dates back to 4004 B.C.E (Jackson 1985:5) in justification of the biblical foundations of the universe, it becomes clear that its main task was to justify a theocratic system that is based on European establishment. The fact that Africans along the Nile valley were already in their $13^{\text {th }}$ dynastic period when Abraham was born, a period when taken back to her $1^{\text {st }}$ dynasty, predates the failed thesis of the existence of Adam and Eve, goes to show to a large extent how we have been whitewashed by the falsification of African history in order to promote and maintain Eurocentric dominance.

Colonialism brings us to a kind of history written by the conqueror for the conquered to read and enjoy. When the conquered looks around 
and finds that even God speaks from the heart of the conqueror, the conquered then becomes suspicious of God (Jochannan \& Clarke 1991:60).

When even history records about twenty-five pre-Christian saviour-gods, all born of virgins, the whole project of Christianity and its subsequent projection of the white race and its enthusiasm to vilify the black race is an indication that raciality and distortion are found in scripture. When even scripture is used by the oppressor to project whiteness, then it becomes evident that Christianity came in the first place, not primarily because there was a messiah to be advertised to the African race that the conqueror wanted the oppressed to be beneficiaries, but because it fosters economic manipulation of the black race. Christianity which therefore teaches that the end does not justify the means, uses her own end as a guide to all other means. We see this been exemplified in the use of the Babylonian Baal to promote the Christian religion, while at the same time condemning such practices as pagan (Jackson 1985:43). The worship of Baal is therefore wrong in Christian theology, but the legend of the Babylonian Bel is right for the propagation of Christian ideology. This use of double standards in Christian doctrine is the very standard that is used to condemn traditional religious practices in African society, while at the same time using the myths of the same African religion to justify Christology. Black becomes demonic, while white is used to represent everything that is honourable. It therefore leaves us amazed that while the image of God and his angelic hosts are Caucasians, the pictorial representation of the devil is black. Those who conceived this notion never averted their minds to the fact that even the devil was part of the angelic hosts before he fell from grace. If everything evil has a black tag, did the devil who is the architect and bearer of evil turn black after the fall, or was he not Caucasian while he was among the angelic hosts? This Christological chauvinism has always been used to cage the African mind in a box, where he justifies slavery in order to condemn everything that is African. It becomes laughable that almost everyone who encounters the divine in a vision always sees the heavenly hosts dressed in the racial colour of his oppressor. This gives him more reasons to justify godliness in his oppressor, while at the same time perceiving godlessness in his fellow black man. And since the person who controls our minds holds the remote to our destiny, in this battle for ideological civilization, African civilization stands the chance of extinction. 


\section{Conclusion}

The right to self-determination is key to the freedom of any people. There is a tendency for colonists to always play the role of 'head of state' that dictates rules for the African continent in the guise of partnerships, although this is not to deny the fact that such has happened to some extent with the connivance of some Africans at some point in history. But since the role of Africans in their plunder is not the crux of this work, we acknowledge the limitation of this paper to make reference to that. Coupled with the wholesale controlled miseducation that stiffles awareness, Western historiography of the black race has been patterned in same instructional direction that must be obeyed. And because knowledge of history brings liberation, there will always be resistance from both masters and even the victims of a misdirectedly ordered history. There is need for a balance of narrative that takes into account all human beings to a point that it bridges, and dispels the vacuity of conflicts. In the midst of scarce resources and political leadership that is sometimes deaf to research, the scholar must still take reasoned and pain-staking steps to deliver the continent from an imperial-centered rhetoric of history, since history as long as it is written for the colonized may never be written in their favour. However, in the reconstruction of history, such proposed narrative should not be humanoid but rather humano-centric.

\section{References}

Ajayi, S.A. (eds.). 2005. African Culture and Civilisations. Ibadan: Atlantis Books.

Ajayi, S.A. \& J.K. Ayantayo (eds.). 2015. Women in Development: Essays in Honour of Professor Dorcas Olubanke Akintunde. Ibadan: John Archers. Awoonor, K. 2006. The African Predicament. Legon: Sub-Saharan Publishers. Ayobade, A. 2012. A Study of Women's Attitude Towards their Socio-

Economic and Political Empowerment: Nigerian Women and National

Development. Global Advanced Research Journal of Management and Business Studies 1,7.

Beiser, F. 2007. 'Historicism'. Leiter, B. \& M. Rosen (eds): The Oxford

Handbook of Continental Philosophy. Oxford: Oxford University Press. Brizuela-García, E. 2006. The History of Africanization and the Africanization of History. History in Africa 33: 85 - 100. 
Browder, A.T. 1996. Survival Strategies for Africans in America: 13 Steps to

Freedom. Washington, DC: The Institute of Karmic Guidance.

DiAngelo, R. 2018. White Fragility. Boston: Beacon Press.

Diop, C. 1987. Precolonial Black Africa. New York: Lawrence Hill Books.

$\mathrm{Du}$ Bois, W.E.B. 1994. The Souls of Black Folk. New York: Dover Publications Inc.

Hegel, G.W.F. 1956. The Philosophy of History. Clarke, J.H. (trans.). New York: Dover.

Iannone, P. 2001. Dictionary of World Philosophy. London: Routledge.

Ilesanmi, O.O. 2014. Efunsatan Aniwura: 'A Psycho-Historical Exploration of

Women's Psychopathology'. International Journal of Information and

Education Technology 4, 2.

Jackson, J. 1985. Christianity before Christ. Texas: American Atheist Press. Jacobson, M. 1999. Whiteness of a Different Color: European Immigrants and the Alchemy of Race. Cambridge, MA: Harvard University Press.

Jahn, J. 1961. Muntu: An Outline of the New African Culture. New York:

Grove Press, Inc.

Jochannan, B. 9 November 2013 NUBIA MOTHER OF EGYPT [TA-

SETI/KUSH MOTHER OF KMT/CHEM]. Available at:

https://www.youtube.com/watch?v=xbZ60FVLmE0

Lamb, J. 2013. Black. Bloomington: Author House.

Malcomson, S. 2001. One Drop of Blood: The American Misadventure of Race. United States: Farrar, Straus and Giroux.

Martinez, E. 2004. Race: The U.S. Creation Myth and its Premise Keepers. Available at:

http://www.cwsworkshop.org/pdfs/WIWS/1Race_US_Creation_Myth.P

DF

Solnit,D. (ed.). 2004. Globalize Liberation: How to Uproot the System and Build a Better World. California: City Light Publishers.

Mudimbe, V.Y. 1994. The Idea of Africa. Indiana: Indiana University Press.

Negedu, I.A. c. 2017. The African Predicament. Internet Encyclopedia of

Philosophy (IEP). Chimakonam, J. (Area Editor.). Available at:

http://www.iep.utm.edu/afr-pred/

Philip, J.E. 2005. What is African History? Philip, J.E. (ed.): Writing African

History. New York: University of Rochester Press.

Popper, K. 2002. The Poverty of Historicism. London: Routledge.

Popper, K. 2013. The Open Society and its Enemies. New Jersey: Princeton 
University Press.

Rensberger, B. $1^{\text {st }}$ March 1979. Nubian Monarchy Called Oldest. New York Times pp. 1 \& A16.

Rubio, P. 2001. A History of Affirmative Action, 1619 - 2000. Mississippi: University Press of Mississippi.

Steinvorth, U. 2009. Rethinking the Western Understanding of the Self. Cambridge: Cambridge University Press.

Sudarkasa, N. 1986. The Status of Women in Indigenous African Societies. Feminist Studies 12, 1.

Williams, C. 1987. The Destruction of Black Civilization: Great Issues of Race from 4500 B.C. to 2000 A.D. Chicago: Third World Press.

Wilson, A. 2014. The Falsification of Afrikan Consciousness: Eurocentric History, Psychiatry and the Politics of White Supremacy. New York: Afrikan World InfoSystems.

Woodson, C. 2010. The Mis-Education of the Negro. New York: Seven Treasures Publications.

Isaiah A. Negedu School of Religion, Philosophy \& Classics College of Humanities Howard College Campus University of Kwazulu-Natal

South Africa NegeduI@ukzn.ac.za

Solomon O. Ojomah Department of Philosophy Federal University Lafia Nasarawa State Nigeria sojomah@gmail.com 